Article

\title{
Effect of Digestate on Soil Organic Carbon and Plant-Available Nutrient Content Compared to Cattle Slurry and Mineral Fertilization
}

\author{
Przemysław Barłóg 1,*(1), Lukáš Hlisnikovský ${ }^{2}$ and Eva Kunzová ${ }^{2}$ \\ 1 Department of Agricultural Chemistry and Environmental Biogeochemistry, \\ Poznan University of Life Sciences, Wojska Polskiego 71F, 60-625 Poznan, Poland \\ 2 Department of Nutrition Management, Crop Research Institute, Drnovská 507, CZ-161 01 Prague 6, Ruzyně, \\ Czechia; 1.hlisnik@vurv.cz (L.H.); kunzova@vurv.cz (E.K.) \\ * Correspondence: przemyslaw.barlog@up.poznan.pl; Tel.: +48-618-48-77-88
}

Received: 23 January 2020; Accepted: 4 March 2020; Published: 10 March 2020

\begin{abstract}
Digestate contains many valuable nutrients, including nitrogen $(\mathrm{N})$, phosphorus $(\mathrm{P})$, and potassium (K); however, it is characterized by relatively little organic matter. The objective of this study was to assess the four-year impact of digestate (Dig) application, digestate + straw (Dig + St), cattle slurry (Csl), and mineral fertilization (NPK) on soil organic carbon (SOC), total nitrogen (TN), mineral $\mathrm{N}\left(\mathrm{N}_{\min }\right)$, and the content of plant-available $\mathrm{P}$ and $\mathrm{K}$. Fertilization did not have any significant influence on SOC, TN, and SOC/TN parameters. Yet, in comparison with control, there was an upward trend in the concentration of SOC and TN in the topsoil, where fertilizers were applied. In contrast to SOC and TN, fertilizer treatment significantly affected the content of $\mathrm{P}, \mathrm{K}$, and $\mathrm{N}_{\min }$, and the differences depended on the soil depth and the fertilizer used. On average, the highest content of $\mathrm{P}$ was obtained in Csl treatment, but the highest content of $\mathrm{K}$ was observed in Dig + St. The effect of treatment on $\mathrm{N}_{\min }$ in spring was as follows: $\mathrm{NPK}=$ control $<\mathrm{Csl}=\mathrm{Dig}+\mathrm{St}<\mathrm{Dig}$. Straw plowing increased the bio-immobilization of $\mathrm{N}$ with digestate and, at the same time, lowered the content level of nitrates in soil.
\end{abstract}

Keywords: biogas slurry; magnesium; mineral nitrogen; priming effect; straw incorporation

\section{Introduction}

In recent years, there has been considerable growth in interest in sustainable production, including the development of an energy industry based on biogas production. Biogas plant operation requires effective management of digestate, a byproduct remaining after the anaerobic digestion of biodegradable feedstock. Recycling of organic matter and nutrients from digestate back to the soil is considered the most sustainable utilization of digestate [1]. The direct application of digestate to soil is considered an inexpensive means of disposal and nutrient recovery for agricultural systems [2]. However, this co-product can also be further refined through various treatments and technologies, commonly known as digestate processing, including solid-liquid separation, drying, dilution, filtration, etc. [3,4].

As a result of anaerobic digestion, a byproduct is obtained with a higher concentration of ammonium ions $\left(\mathrm{NH}_{4}{ }^{+}\right)$in relation to total $\mathrm{N}$ than the original organic feedstock [5]. Nitrogen, incorporated into the soil with digestate, undergoes various transformations such as mineralization, immobilization, nitrification, etc. [6]. In general, the mineral $\mathrm{N}$ from digestate is hardly immobilized in soil because of the low carbon $(\mathrm{C}) / \mathrm{N}$ ratio and the content of highly stable organic substances [7]. At the same time, once incorporated into the soil, $\mathrm{NH}_{4}{ }^{+}$ions undergo an immediate process of nitrification $[2,8,9]$. Tambone and Adani [10] reported that digestate derived from sewage sludge demonstrated not only 
a high rate of nitrification but also mineralization of organic matter. Consequently, the fertilizer's capacity to supply plants with mineral $\mathrm{N}$ was comparable with urea. Some studies also indicate that digestate application leads to stimulation of soil organic matter (SOM) decomposition, named the "priming effect" [11,12]. As a result, the soil gains an additional pool of mineral $\mathrm{N}$ readily available for plants [13]. On the other hand, application of digestate carries a risk of excess ammonia $\left(\mathrm{NH}_{3}\right)$ volatilization and/or dispersal of oxidized forms of $\mathrm{N}$, through nitrate ions $\left(\mathrm{NO}_{3}{ }^{-}\right)$leaching or nitrous oxide $\left(\mathrm{N}_{2} \mathrm{O}\right)$ emission [14-17]. Moreover, high rates of digestate application may trigger phytotoxic $\mathrm{NH}_{3}$ [18].

The high fertilizing potential of digestate is also associated with a high content of plant-available $\mathrm{P}$ and $\mathrm{K}$, and other nutrients [19-21]. The solid part of the digestate contains both inorganic and organic $\mathrm{P}$, but in the liquid part, inorganic $\mathrm{P}$ dominates [22,23]. Application of digestate may influence the content of plant-available $\mathrm{P}$ in soil directly through incorporating inorganic $\mathrm{P}$ and/or indirectly through prompting microorganisms to undergo various activities [24]. The direction of the organic $P$ transformations depends on the $\mathrm{C} / \mathrm{P}$ ratio in the organic matter, while in case of inorganic $\mathrm{P}$ it depends on the soil $\mathrm{pH}$ and the presence of metal cations $[25,26]$. In non-calcareous soils, inorganic $\mathrm{P}$ in soil solutions ( $\mathrm{Pi})$ is strongly sorbed to metal oxi(hydro)oxides of mainly iron $(\mathrm{Fe})$ and aluminum $(\mathrm{Al})$, and in soils with a high concentration of exchangeable calcium (Ca), precipitation of Ca-phosphate minerals occurs. However, decomposition products from manure or organic fertilizers such as organic acid anions and/or humic acids can compete with Pi for the same sorption sites (ligand exchange) or solubilize Pi via ligand-promoted mineral dissolution [27,28]. According to Bahmann et al. [23], application of digestate increased the content of plant-available $P$ in the soil to the same extent as highly soluble mineral P fertilizer (Triple Super Phosphate) and undigested dairy slurry. In contrast to P, K in digestate is directly plant-available as free $\mathrm{K}^{+}$ions, in both solid and liquid phase [20]. The digestate application improves the nutrient reserves in soil and boosts the soil capacity of the nutrient supply to plants. Only on light soils, $\mathrm{K}$ from digestate in excess of plant requirements was leached from the soil [9].

Digestates contain less organic $C$ than feedstock [3,29]. However, Möller [6] concluded that the loss of organic $C$ during the anaerobic digestion process is compensated by lower organic $C$ degradation after an application of digestates. Long-term experiments did not prove any negative impact of digestate application on SOC content when compared to treatment with manure and/or slurries $[24,30,31]$. Nevertheless, some authors suggest that digestate fractionation or composting may improve the $C$ sequestration in soils $[32,33]$. Tivari et al. [34] suggest that maintaining an adequate level of SOC with years-long application of digestate requires an additional source of organic $C$, which is mainly provided by incorporating crop residues into soil, especially cereal straw. Straw is responsible for the recycling of $C$, as well as other elements, including P and K [35-37].

In this study, it was hypothesized that the influence of digestate application on the basic soil proportion and the content of mineral $\mathrm{N}$ as well as plant-available macronutrients depends on the management of cereal straw. In order to verify this hypothesis, four-year-long studies were carried out to determine the influence of digestate application, with or without straw incorporation, on the content of (i) soil organic carbon and total nitrogen, (ii) soil mineral nitrogen, and (iii) plant-available $\mathrm{P}$, $\mathrm{K}$, and $\mathrm{Mg}$. The effect of digestate fertilization treatment on these features was compared with the effects of cattle slurry and NPK mineral fertilization.

\section{Materials and Methods}

\subsection{Site Description}

The experimental field is located in Prague-Ruzyně, Czech Republic (50.089144 N, 14.289997 E). According to the soil classification by the World Reference Base for Soil Resources [38], the soil type of the study site is Orthic Luvisol, formed by diluvial sediments mixed with loess. The arable layer of soil $(0.0-0.3 \mathrm{~m})$ is characterized by clay loam soil texture (clay content $=27 \%$ ). Prior to the experiment, 
$\mathrm{pH}(\mathrm{KCl})$ was neutral, and SOC and TN content were at levels of 15.6 and $1.66 \mathrm{~g} \mathrm{~kg}^{-1}$, respectively. Topsoil was characterized by good content of plant-available $\mathrm{K}$ and $\mathrm{Ca}$, moderate content of magnesium $(\mathrm{Mg})$, and suitable content of $\mathrm{P}$. The subsoil was characterized by a slightly higher $\mathrm{pH}$ and $\mathrm{Ca}$ and $\mathrm{Mg}$ content but lower $\mathrm{P}$ and $\mathrm{K}$ content in comparison with the topsoil. The nitrate $\mathrm{N}\left(\mathrm{NO}_{3}-\mathrm{N}\right)$ content was $29.2 \%$ higher in the subsoil than in the topsoil. Compared to $\mathrm{NO}_{3}-\mathrm{N}$, the content of ammonium $\mathrm{N}$ $\left(\mathrm{NH}_{4}-\mathrm{N}\right)$ was several times lower, regardless of the soil depth. The total amount of $\mathrm{N}_{\min }$ in the soil depth 0.0-0.6 m (total sum of $\mathrm{NO}_{3}-\mathrm{N}$ and $\mathrm{NH}_{4}-\mathrm{N}$ ) was overall $91.9 \mathrm{~kg} \mathrm{ha}^{-1}$ (Table 1).

Table 1. Soil properties (mean \pm standard error of the mean) of experimental site after harvest of preceding crop and before setting up the experiment, August $2012(n=5)$.

\begin{tabular}{ccc}
\hline Parameter & Soil Depth: 0.0-0.3 m & Soil Depth: 0.3-0.6 m \\
\hline $\mathrm{pH}$ & $7.22 \pm 0.038$ & $7.33 \pm 0.13$ \\
$\mathrm{SOC}, \mathrm{g} \mathrm{kg}^{-1}$ & $15.6 \pm 0.3$ & $10.6 \pm 0.3$ \\
$\mathrm{TN}, \mathrm{g} \mathrm{kg}^{-1}$ & $1.66 \pm 0.012$ & $1.02 \pm 0.031$ \\
$\mathrm{SOC} / \mathrm{TN}^{-1}$ & $9.43 \pm 0.23$ & $10.34 \pm 0.29$ \\
$\mathrm{P}{ }^{1}, \mathrm{mg} \mathrm{kg}^{-1}$ & $535.0 \pm 9.2$ & $311.4 \pm 6.2$ \\
$\mathrm{~S}^{1}, \mathrm{mg} \mathrm{kg}^{-1}$ & $308.2 \pm 3.3$ & $160.5 \pm 4.7$ \\
$\mathrm{~K}^{1}, \mathrm{mg} \mathrm{kg}^{-1}$ & $6298 \pm 194$ & $6686 \pm 238$ \\
$\mathrm{Mg}^{1}, \mathrm{mg} \mathrm{kg}^{-1}$ & $4130 \pm 40$ & $5508 \pm 64$ \\
$\mathrm{Ca}^{1}, \mathrm{mg} \mathrm{kg}^{-1}$ & $6334 \pm 230$ & $6174 \pm 67$ \\
$\mathrm{Zn}^{1}, \mathrm{mg} \mathrm{kg}^{-1}$ & $71.2 \pm 0.6$ & $62.7 \pm 0.4$ \\
$\mathrm{Mn}^{1}, \mathrm{mg} \mathrm{kg}^{-1}$ & $569.8 \pm 4.1$ & $571.0 \pm 15.8$ \\
$\mathrm{Cu}^{1}, \mathrm{mg} \mathrm{kg}^{-1}$ & $24.5 \pm 0.4$ & $15.4 \pm 0.7$ \\
$\mathrm{P}^{2}, \mathrm{mg} \mathrm{kg}^{-1}$ & $85.8 \pm 3.70$ & $15.4 \pm 2.46$ \\
$\mathrm{~K}^{2}, \mathrm{mg} \mathrm{kg}^{-1}$ & $215.1 \pm 5.99$ & $146.8 \pm 6.26$ \\
$\mathrm{Mg}^{2}, \mathrm{mg} \mathrm{kg}^{-1}$ & $130.6 \pm 2.68$ & $187.3 \pm 5.16$ \\
$\mathrm{Ca}^{2}, \mathrm{mg} \mathrm{kg}^{-1}$ & $4472.3 \pm 90.1$ & $5231.4 \pm 87.3$ \\
$\mathrm{NH}_{4}-\mathrm{N}, \mathrm{mg} \mathrm{kg}^{-1}$ & $0.17 \pm 0.07$ & $0.20 \pm 0.07$ \\
$\mathrm{NO}_{3}-\mathrm{N}, \mathrm{mg} \mathrm{kg}^{-1}$ & $9.73 \pm 0.34$ & $11.7 \pm 0.92$ \\
$\mathrm{~N}_{\mathrm{min}}, \mathrm{kg} \mathrm{ha}^{-1}$ & $40.1 \pm 1.55$ & $51.8 \pm 4.27$ \\
\hline
\end{tabular}

${ }^{1}$ Total content. ${ }^{2}$ Plant-available content.

The site is located at an altitude of $370 \mathrm{~m}$ a.s.l., the average annual temperature is $8.2^{\circ} \mathrm{C}$, and the annual precipitation reaches about $450-500 \mathrm{~mm}$. The monthly rainfall and average air temperature during the experiment are presented in Figure S1.

\subsection{Experimental Design}

A randomized complete block design was executed with four replications, and the following treatments were used: without fertilizers (control), digestate (Dig), digestate + straw (Dig $+\mathrm{St})$, cattle slurry (Csl), and mineral NPK fertilizers (NPK). The total number of plots was 20, and the area of an individual plot was $30 \mathrm{~m}^{2}(3 \times 10 \mathrm{~m})$. Annual doses of fresh matter of digestate and cattle slurry were constant during the trials (Table 2). In Dig + St treatment, the straw was cut and incorporated into the soil via plowing (to a depth of $10 \mathrm{~cm}$ ) after the harvest. In the other treatments, the straw was removed from the experimental plots after harvest. The digestate was applied before tillage in the autumn (September), so straw and digestate in Dig + St treatment was applied separately, without mixing together (the straw was already incorporated into the soil at the time of tillage). In the case of spring barley, the digestate was applied before the tillage in autumn (November). Both fertilizers (digestate and slurry) were applied on the soil surface by hose applicator and immediately plowed. In NPK treatment, annual doses of P and K were constant during the trials. However, the doses of mineral $\mathrm{N}$ depended on the year and crop.

Mineral $\mathrm{N}$ in the form of calcium ammonium nitrate $\left(5 \mathrm{Ca}\left(\mathrm{NO}_{3}\right)_{2} \times \mathrm{NH}_{4} \mathrm{NO}_{3} \times 10 \mathrm{H}_{2} \mathrm{O} ; 27 \% \mathrm{~N}\right.$ $\left(13.5 \% \mathrm{NO}_{3}-\mathrm{N}\right.$ and $\left.\left.13.5 \% \mathrm{NH}_{4}-\mathrm{N}\right)+4.0 \% \mathrm{MgO}+6.0 \% \mathrm{CaO}\right)$ was applied at the beginning of spring vegetation, when the first node became visible, and at the beginning of heading. According to these growth stages, the full $\mathrm{N}$ dose was divided into proportions of $50 \%, 30 \%$, and $20 \%$, respectively. 
In respect to fertilization of spring barley, the first $\mathrm{N}$ dose was applied before sowing $(60 \%)$ and the second one at the beginning of stem elongation ( $40 \%$ of full $\mathrm{N}$ dose). Fertilizers with $\mathrm{K}$ (potassium chloride $(\mathrm{KCl}) 60 \% \mathrm{~K}_{2} \mathrm{O}$ ) and $\mathrm{P}$ (superphosphate $\left.\left(\mathrm{Ca}\left(\mathrm{H}_{2} \mathrm{PO}_{4}\right)_{2}\right) 45 \% \mathrm{P}_{2} \mathrm{O}_{5}\right)$ were applied in autumn following the harvest of the preceding crop. The sequence in the crop rotation was as follows: winter wheat (Triticum aestivum L.), winter wheat, spring barley (Hordeum vulgaris L.), winter wheat (Table 2).

Table 2. Crop rotation and doses of manure, organic, and mineral fertilizers depending on crop and treatment.

\begin{tabular}{|c|c|c|c|c|c|c|}
\hline \multirow[b]{2}{*}{$\begin{array}{l}\text { Harvest } \\
\text { Season }\end{array}$} & \multirow[b]{2}{*}{ Crop } & \multicolumn{5}{|c|}{ Treatment/Doses of Fertilizers } \\
\hline & & Control & $\begin{array}{c}\text { Dig1 }^{\text {t ha }} \\
\text { h1 }\end{array}$ & $\begin{array}{c}\mathrm{Dig}^{1}+\mathrm{St}^{2} \\
\mathrm{hha}^{-1}\end{array}$ & $\begin{array}{c}\text { Csl }^{1} \\
\text { tha }^{-1}\end{array}$ & $\begin{array}{c}\text { NPK } \\
\mathrm{kg} \mathrm{ha}^{-1}\end{array}$ \\
\hline 2013 & Winter wheat & 0 & 20 & $20+5-7$ & 30 & $120-30-90$ \\
\hline 2014 & Winter wheat & 0 & 20 & $20+5-7$ & 30 & $140-30-90$ \\
\hline 2015 & Spring barley & 0 & 20 & $20+5-7$ & 30 & $90-30-90$ \\
\hline 2016 & Winter wheat & 0 & 20 & $20+5-7$ & 30 & $140-30-90$ \\
\hline
\end{tabular}

${ }^{1}$ As fresh matter (FM). ${ }^{2}$ At content of $85 \%$ dry matter (DM). Csl, cattle slurry; Dig, digestate application; Dig + St, digestate + straw; NPK, mineral fertilizers.

Winter wheat (cv. Mulan) was sown on the following dates: 26 September 2012, 30 September 2013, and 5 October 2015. The seed rate in each year was $180 \mathrm{~kg} \mathrm{ha}^{-1}$. The sowing date of spring barley (cv. Sebastian) was 18 March 2015, and the seed rate was $230 \mathrm{~kg} \mathrm{ha}^{-1}$. The preceding crop was field pea (before the start of the experiment, the pea straw was removed from the field). Winter wheat and spring barley were harvested in July each year, using a Sampo combine harvester.

\subsection{Chemical Characteristics of Fertilizers}

Digestate and cattle slurry used in the experiment originated from the Kačina farm (Czech Republic). The feedstock for biogas production was cattle slurry, maize silage, and haylage. Both fertilizers were characterized by a similar content of dry matter (DM). The TN, P, K Ca, S, and Fe in DM of digestate was higher than in cattle slurry (Table 3).

Table 3. Chemical properties of digestate, cattle slurry, and straw and annual input of dry matter and nutrients into soil with fertilizers (mean value \pm standard deviation, $n=4$ ).

\begin{tabular}{|c|c|c|c|c|c|c|}
\hline \multirow{2}{*}{ Parameter } & \multicolumn{3}{|c|}{ Chemical Properties of Fertilizers } & \multicolumn{3}{|c|}{ Input in Treatments } \\
\hline & Digestate & Cattle Slurry & Straw & Dig & Csl & $\mathrm{Dig}+\mathrm{St}$ \\
\hline \multirow[t]{2}{*}{$\mathrm{pH}$} & $8.53 \pm 0.17$ & $7.62 \pm 0.47$ & - & - & - & - \\
\hline & \multicolumn{3}{|c|}{$\% \mathrm{FM}$} & \multicolumn{3}{|c|}{$\mathrm{tha}^{-1}$} \\
\hline \multirow[t]{2}{*}{$\mathrm{DM}$} & $5.83 \pm 0.53$ & $5.72 \pm 2.33$ & 85.0 & $1.17 \pm 1.1$ & $1.72 \pm 0.70$ & $6.27 \pm 1.41$ \\
\hline & \multicolumn{3}{|c|}{$\mathrm{g} \mathrm{kg}^{-1} \mathrm{DM}$} & \multicolumn{3}{|c|}{$\mathrm{kg} \mathrm{ha}^{-1}$} \\
\hline TN & $31.4 \pm 2.0$ & $24.0 \pm 1.2$ & $3.1 \pm 0.8$ & $36.6 \pm 4.4$ & $40.4 \pm 15.4$ & $55.2 \pm 5.0$ \\
\hline$P$ & $11.7 \pm 0.5$ & $9.4 \pm 5.6$ & $0.39 \pm 0.14$ & $13.7 \pm 2.3$ & $12.4 \pm 3.7$ & $16.0 \pm 1.4$ \\
\hline $\mathrm{K}$ & $55.9 \pm 9.2$ & $35.9 \pm 19.1$ & $10.1 \pm 4.6$ & $64.5 \pm 8.8$ & $48.8 \pm 18.7$ & $123.4 \pm 17.6$ \\
\hline $\mathrm{Ca}$ & $29.6 \pm 2.8$ & $23.5 \pm 9.6$ & $3.2 \pm 0.9$ & $34.4 \pm 3.9$ & $34.2 \pm 13.8$ & $53.5 \pm 5.4$ \\
\hline $\mathrm{Mg}$ & $8.24 \pm 0.57$ & $8.55 \pm 4.98$ & $0.62 \pm 0.06$ & $9.6 \pm 0.5$ & $11.3 \pm 4.2$ & $13.3 \pm 0.4$ \\
\hline $\mathrm{S}$ & $4.89 \pm 0.55$ & $4.02 \pm 1.78$ & $0.56 \pm 0.11$ & $5.6 \pm 0.2$ & $5.7 \pm 2.1$ & $9.0 \pm 0.3$ \\
\hline \multirow[t]{2}{*}{$\mathrm{Na}$} & $3.99 \pm 0.79$ & $5.17 \pm 3.23$ & $0.43 \pm 0.36$ & $4.6 \pm 0.9$ & $6.7 \pm 2.5$ & $7.01 \pm 2.73$ \\
\hline & \multicolumn{3}{|c|}{$\mathrm{mg} \mathrm{kg}^{-1} \mathrm{DM}$} & \multicolumn{3}{|c|}{$\mathrm{g} \mathrm{ha}^{-1}$} \\
\hline $\mathrm{Zn}$ & $295.0 \pm 51.9$ & $387.8 \pm 99.9$ & $5.91 \pm 1.87$ & $344 \pm 78$ & $516 \pm 177$ & $380 \pm 49$ \\
\hline $\mathrm{Cu}$ & $90.1 \pm 62.3$ & $95.0 \pm 51.6$ & $2.08 \pm 0.31$ & $111 \pm 105$ & $130 \pm 57$ & $124 \pm 74$ \\
\hline Mn & $285.7 \pm 3.9$ & $245.6 \pm 94.6$ & $26.5 \pm 8.1$ & $334 \pm 42$ & $361 \pm 139$ & $496 \pm 40$ \\
\hline $\mathrm{Fe}$ & $2962 \pm 669$ & $1446 \pm 721$ & $37.6 \pm 18.1$ & $3428 \pm 836$ & $2036 \pm 1017$ & $3664 \pm 591$ \\
\hline
\end{tabular}

FM, fresh matter; DM, dry matter; TN, total nitrogen. 
The DM of cattle slurry contained higher amounts of $\mathrm{Mg}, \mathrm{Na}, \mathrm{Cu}$, and $\mathrm{Zn}$ than digestate. Comparing both fertilizers, DM of straw showed very low macronutrient and micronutrient content.

\subsection{Soil Sampling and Analysis}

Soil samples were collected from each plot twice a year, in the spring prior to mineral $\mathrm{N}$ fertilization and in the autumn after harvest, before the application of digestate and cattle slurry. Soil samples were taken at two depths, $0.0-0.3$ and $0.3-0.6 \mathrm{~m}$. $\mathrm{NH}_{4}-\mathrm{N}$ and $\mathrm{NO}_{3}-\mathrm{N}$ were determined in field-fresh (not air-dried) soil samples. For determination, $30 \mathrm{~g}$ soil samples were shaken for $1 \mathrm{~h}$ with $150 \mathrm{~mL}$ of a $1 \% \mathrm{~K}_{2} \mathrm{SO}_{4}$ solution (soil/solution ratio $\left.5: 1 ; w / v\right)$. After filtering through filter paper, concentrations of $\mathrm{NH}_{4}-\mathrm{N}$ and $\mathrm{NO}_{3}-\mathrm{N}$ in solutions were determined by the colorimetric method using flow injection analysis (San++ system, Skalar, De Breda, the Netherlands). $\mathrm{NH}_{4}-\mathrm{N}$ and $\mathrm{NO}_{3}-\mathrm{N}$ content was expressed in $\mathrm{mg} \mathrm{kg}^{-1}$ air-dried soil. Total $\mathrm{N}_{\text {min }}$ was calculated as the sum of $\mathrm{NH}_{4}-\mathrm{N}$ and $\mathrm{NO}_{3}-\mathrm{N}$ for $0.0-0.6 \mathrm{~m}$ soil depth, using converters of 4.05 and 4.35 in relation to soil bulk density and soil depth, respectively (topsoil $=1.35 \mathrm{~g} \mathrm{~cm}^{-3}$; subsoil $=1.45 \mathrm{~g} \mathrm{~cm}^{-3}$ ).

The soil samples collected in autumn were air-dried and sieved to $<2 \mathrm{~mm}$. The $\mathrm{pH}$ was determined by the potentiometric method as follows: $20 \mathrm{~g}+50 \mathrm{~mL}$ of $0.2 \mathrm{M} \mathrm{KCl}$ (inoLab pH 730, WTW, Weilheim, Germany). Soil organic carbon (SOC), total nitrogen (TN), and total sulfur (S) were determined by using a Vario Max analyzer (Elementar Analysensysteme GmbH, Hanau, Germany). Content of the plant-available form of $\mathrm{P}, \mathrm{K}, \mathrm{Mg}$, and $\mathrm{Ca}$ was determined by the Mehlich 3 method [39]. The (pseudo)total nutrient content in soil $(\mathrm{P}, \mathrm{K}, \mathrm{Mg}, \mathrm{Ca}, \mathrm{Cu}, \mathrm{Mn}, \mathrm{Zn})$ was determined in $1 \mathrm{~g}$ of subsamples after decomposition in digestion vessels mixed with aqua regia (1:3 mixture of nitric acid and hydrochloric acid). For digestion, the MLS-1200 mega microwave system (Milestone Inc., Sorisole, Italy) was used. The concentration of elements in the soil digests and extracts was determined by optical emission spectroscopy with inductively coupled plasma (ICP-OES; Thermo Jarrell-Ash Trace Scan, Franklin, MA, USA).

\subsection{Statistical Analysis}

In order to assess the influence of treatments on soil quality parameters, two-way ANOVA was applied, evaluating the effects of individual research factors (year, fertilizer treatments) and their interactions. The distribution of the data (normality) was checked using the Shapiro-Wilk test. To improve the statistical modelling, the individual variables that did not have a normal distribution were power transformed with positive exponents within the Box-Cox framework in order to achieve normality. The homogeneity of variance was checked by Bartlett's test. Means were separated by honest significant difference (HSD) using Tukey's method when the F-test indicated significant factorial effects at the level of $p<0.05$. Data in the tables and figures are presented as non-transformed data. Data were calculated as arithmetic means with standard error of the mean (SEM). Principal component analysis (PCA) was applied for evaluation of relationships between variables. The original data were standardized before the analysis. The maximum number of principal components (PCs) taken into account for further analysis depended on the individual variance. In the present study, only factors with eigenvalue $>1$ were considered (Kaiser's criterion). Statistica 13 software was used for all statistical analyses [40].

\section{Results}

\subsection{Soil Organic Carbon and Total Nitrogen}

In our study, the main factor determining SOC content was the year. According to the year, SOC values ranged from 14.8 (2016) to $15.6 \mathrm{~g} \mathrm{~kg}^{-1}$ (2013) in topsoil, and from 7.5 (2015) to $10.4 \mathrm{~g} \mathrm{~kg}^{-1}$ (2013) in subsoil. The fertilization treatments did not have any significant influence on SOC in any year of the experiment. The factor also had no significant impact on the average values for four years. However, in comparison with control and NPK treatment, there was an upward trend in the concentration of 
SOC where digestate, digestate + straw, and cattle slurry were applied. On average, in the course of the four-year experiment, a slightly higher SOC level was recorded in the Dig treatment. The lowest SOC content was obtained in NPK and control, regardless of the depth of soil sampling (Table 4).

Table 4. Soil organic carbon (SOC), total nitrogen (NT), and SOC/TN ratio as a result of different crop residue management and application of manure, organic, and mineral fertilizers (mean for 4 years \pm standard error of the mean).

\begin{tabular}{|c|c|c|c|c|c|c|}
\hline \multirow[b]{2}{*}{ Parameter } & \multicolumn{3}{|c|}{ Soil Depth: $0.0-0.3 \mathrm{~m}$} & \multicolumn{3}{|c|}{ Soil Depth: $0.3-0.6 \mathrm{~m}$} \\
\hline & $\begin{array}{c}\mathrm{SOC} \\
\mathrm{g} \mathrm{kg}^{-1}\end{array}$ & $\begin{array}{c}\mathrm{TN} \\
\mathrm{g} \mathrm{kg}^{-1}\end{array}$ & SOC/TN & $\begin{array}{c}\mathrm{SOC} \\
\mathrm{g} \mathrm{kg}^{-1}\end{array}$ & $\begin{array}{c}\mathrm{TN} \\
\mathrm{g} \mathrm{kg}^{-1}\end{array}$ & SOC/TN \\
\hline Control & $15.2 \pm 0.3$ & $1.48 \pm 0.03$ & $10.3 \pm 0.3$ & $8.6 \pm 0.4$ & $0.89 \pm 0.03$ & $9.9 \pm 0.3$ \\
\hline Dig & $15.6 \pm 0.3$ & $1.53 \pm 0.03$ & $10.2 \pm 0.3$ & $9.3 \pm 0.3$ & $0.97 \pm 0.03$ & $9.8 \pm 0.3$ \\
\hline $\mathrm{Dig}+\mathrm{St}$ & $15.5 \pm 0.2$ & $1.51 \pm 0.02$ & $10.3 \pm 0.2$ & $8.7 \pm 0.3$ & $0.92 \pm 0.04$ & $9.7 \pm 0.3$ \\
\hline Csl & $15.4 \pm 0.2$ & $1.51 \pm 0.03$ & $10.3 \pm 0.2$ & $9.0 \pm 0.4$ & $0.95 \pm 0.03$ & $9.7 \pm 0.3$ \\
\hline NPK & $15.3 \pm 0.2$ & $1.49 \pm 0.03$ & $10.3 \pm 0.2$ & $8.5 \pm 0.4$ & $0.90 \pm 0.03$ & $9.6 \pm 0.2$ \\
\hline
\end{tabular}

The content of TN, according to the year, ranged from 1.42 (2015) to $1.64 \mathrm{~g} \mathrm{~kg}^{-1}$ (2014) in topsoil and from 0.76 (2015) to $1.03 \mathrm{~g} \mathrm{~kg}^{-1}$ (2014) in subsoil. The fertilization treatments did not have any significant influence on TN. The differences were negligible; however, an upward trend of TN accumulation in Dig, Dig + St, and Csl treatments was seen, especially in subsoil. The lowest SOC content was obtained in NPK and control treatments, regardless of the depth of soil sampling. The SOC/TN ratio in the topsoil ranged from 9.4 to 11.0 and in the subsoil from 8.9 to 10.3, depending on the year. Fertilization did not have a significant effect on the studied parameter (Table 4).

\subsection{Soil $p H$}

The only factor with a significant influence on soil $\mathrm{pH}$ was the year. As the experiment continued, the mean $\mathrm{pH}$ value systematically decreased. As a result, the mean $\mathrm{pH}$ value in topsoil in 2016 was 0.2 units lower than in 2013 and 0.3 units lower than in 2012. Fertilization did not differentiate $\mathrm{pH}$ values in any year of the study. Moreover, it had no significant impact on mean values (Figure S2).

\subsection{Plant-Available Nutrients}

Fertilization did not have any significant influence on the content of plant-available $\mathrm{P}$ in soil in any year of the study, regardless of the soil depth (Table 5). However, every year, an upward trend in the nutrient content level was observed, which mainly concerned two treatments, Dig and Csl. In 2013-2014, the highest P content in topsoil was found in the Csl treatment, in 2015 in the Csl and Dig, and in 2016 in the Dig. Consequently, a significant impact of the fertilization on the mean content of $\mathrm{P}$ was found in both soil layers $(p<0.05$ and $p<0.01)$. In topsoil, a significant difference was registered between two treatments, control and Csl. In contrast to topsoil, the soil in Csl treatment contained considerably more P than in Dig + St and control.

In each individual year of the study, fertilization did not exert any significant influence on plant-available K. In topsoil, however, every year showed a clear upward trend of K concentration as a result of fertilization, particularly in the Dig + St treatment. Consequently, average K content in this treatment was significantly higher than in control, Csl, and NPK fertilizer treatments $(p<0.001)$. Compared to topsoil, no crucial difference between treatments was reported in soil depth between 0.3 and $0.6 \mathrm{~m}$. The studied factor did not exert any significant impact on the content of plant-available Ca or Mg. The obtained dissimilarities between treatments depended on the year of study and were not very explicit (Table 5).

In contrast to the plant-available $\mathrm{P}$ and $\mathrm{K}$, the four-year study showed that application of fertilizers did not affect the (pseudo)total content of $\mathrm{P}$ and $\mathrm{S}$ and other nutrients in the soil (Table S1). 
Table 5. Plant-available $\mathrm{P}, \mathrm{K}, \mathrm{Mg}$, and $\mathrm{Ca}$ in soil samples $\left(\mathrm{mg} \mathrm{kg}^{-1}\right)$ determined by Mehlich 3 method as a result of application of digestate (Dig), digestate + straw $(\mathrm{Dig}+\mathrm{St})$, cattle slurry $(\mathrm{Csl})$, and mineral fertilizers (NPK).

\begin{tabular}{|c|c|c|c|c|c|c|}
\hline \multirow{2}{*}{ Parameter } & \multirow{2}{*}{ Treatment } & \multicolumn{4}{|c|}{ Year } & \multirow{2}{*}{ Mean } \\
\hline & & 2013 & 2014 & 2015 & 2016 & \\
\hline \multicolumn{7}{|c|}{ Soil depth: $0.0-0.3 \mathrm{~m}$} \\
\hline \multirow[t]{5}{*}{$\mathrm{P}$} & Control & $80.9 \pm 3.2$ & $81.7 \pm 6.0$ & $96.3 \pm 6.8$ & $77.1 \pm 3.6$ & $84.0 \pm 3.1^{b}$ \\
\hline & Dig & $81.5 \pm 3.2$ & $92.5 \pm 8.1$ & $110.5 \pm 8.8$ & $87.0 \pm 2.9$ & $92.9 \pm 4.0^{\mathrm{a}, \mathrm{b}}$ \\
\hline & Dig + St & $86.9 \pm 3.4$ & $73.3 \pm 1.8$ & $103.1 \pm 4.1$ & $83.6 \pm 5.5$ & $86.7 \pm 3.3^{\mathrm{a}, \mathrm{b}}$ \\
\hline & Csl & $90.8 \pm 3.7$ & $93.4 \pm 2.2$ & $109.9 \pm 8.7$ & $83.1 \pm 5.6$ & $94.3 \pm 3.6^{\mathrm{a}}$ \\
\hline & NPK & $88.0 \pm 6.5$ & $91.4 \pm 1.6$ & $103.5 \pm 4.4$ & $80.8 \pm 3.3$ & $90.9 \pm 2.9^{a, b}$ \\
\hline \multirow[t]{5}{*}{ K } & Control & $204.1 \pm 3.8$ & $206.8 \pm 6.1$ & $221.0 \pm 3.8$ & $212.9 \pm 10.6$ & $211.2 \pm 3.4^{\mathrm{c}}$ \\
\hline & Dig & $210.6 \pm 4.9$ & $252.2 \pm 25.9$ & $236.3 \pm 12.2$ & $241.4 \pm 5.3$ & $235.1 \pm 7.7^{\mathrm{a}, \mathrm{b}}$ \\
\hline & $\mathrm{Dig}+\mathrm{St}$ & $240.7 \pm 6.6$ & $255.1 \pm 2.1$ & $246.7 \pm 9.9$ & $243.8 \pm 3.6$ & $246.6 \pm 3.2^{\mathrm{a}}$ \\
\hline & Csl & $223.3 \pm 14.5$ & $230.3 \pm 8.5$ & $218.5 \pm 9.4$ & $218.1 \pm 7.8$ & $222.6 \pm 4.8^{b, c}$ \\
\hline & NPK & $218.3 \pm 12.8$ & $232.7 \pm 3.8$ & $230.7 \pm 8.0$ & $219.9 \pm 5.8$ & $225.4 \pm 4.1^{\mathrm{b}, \mathrm{c}}$ \\
\hline \multirow[t]{5}{*}{$\mathrm{Mg}$} & Control & $137.0 \pm 5.4$ & $122.9 \pm 3.0$ & $136.3 \pm 7.7$ & $144.0 \pm 3.1$ & $135.0 \pm 3.0$ \\
\hline & Dig & $136.8 \pm 6.3$ & $121.5 \pm 1.5$ & $142.1 \pm 2.7$ & $152.5 \pm 5.1$ & $138.2 \pm 3.5$ \\
\hline & Dig + St & $143.5 \pm 2.3$ & $130.8 \pm 1.3$ & $151.1 \pm 2.9$ & $152.6 \pm 0.8$ & $144.5 \pm 2.4$ \\
\hline & Csl & $145.8 \pm 1.8$ & $128.7 \pm 2.7$ & $145.6 \pm 4.3$ & $155.8 \pm 2.9$ & $144.0 \pm 2.9$ \\
\hline & NPK & $143.5 \pm 2.9$ & $127.3 \pm 1.5$ & $158.7 \pm 2.1$ & $147.6 \pm 2.6$ & $144.3 \pm 5.7$ \\
\hline \multirow[t]{5}{*}{$\mathrm{Ca}$} & Control & $4446 \pm 167$ & $4391 \pm 106$ & $4428 \pm 115$ & $4450 \pm 175$ & $4429 \pm 65$ \\
\hline & Dig & $4405 \pm 202$ & $4295 \pm 49$ & $4394 \pm 196$ & $4621 \pm 309$ & $4428 \pm 99$ \\
\hline & $\mathrm{Dig}+\mathrm{St}$ & $4329 \pm 173$ & $4539 \pm 200$ & $4460 \pm 200$ & $4647 \pm 272$ & $4494 \pm 100$ \\
\hline & Csl & $4373 \pm 94$ & $4508 \pm 52$ & $4354 \pm 121$ & $4975 \pm 428$ & $4553 \pm 121$ \\
\hline & NPK & $4590 \pm 105$ & $4614 \pm 123$ & $4635 \pm 233$ & $4869 \pm 255$ & $4677 \pm 90$ \\
\hline \multicolumn{7}{|c|}{ Soil depth: $0.3-0.6 \mathrm{~m}$} \\
\hline \multirow[t]{5}{*}{$\mathrm{P}$} & Control & $43.0 \pm 3.8$ & $44.8 \pm 8.3$ & $16.4 \pm 5.9$ & $23.6 \pm 1.3$ & $31.9 \pm 4.0^{\mathrm{b}}$ \\
\hline & Dig & $49.0 \pm 3.5$ & $48.8 \pm 0.7$ & $22.4 \pm 4.0$ & $29.5 \pm 3.6$ & $37.4 \pm 3.4^{\mathrm{a}, \mathrm{b}}$ \\
\hline & $\mathrm{Dig}+\mathrm{St}$ & $45.9 \pm 5.5$ & $31.2 \pm 2.9$ & $21.3 \pm 5.1$ & $29.0 \pm 3.8$ & $31.8 \pm 3.0^{b}$ \\
\hline & Csl & $55.5 \pm 3.3$ & $54.6 \pm 2.7$ & $26.0 \pm 6.0$ & $31.7 \pm 2.8$ & $42.0 \pm 3.9^{\mathrm{a}}$ \\
\hline & NPK & $50.3 \pm 4.4$ & $45.9 \pm 2.3$ & $12.7 \pm 2.9$ & $26.5 \pm 1.6$ & $33.8 \pm 4.1^{\mathrm{a}, \mathrm{b}}$ \\
\hline \multirow[t]{5}{*}{$\mathrm{K}$} & Control & $150.4 \pm 4.9$ & $187.2 \pm 7.1$ & $195.2 \pm 7.3$ & $154.2 \pm 2.7$ & $171.8 \pm 5.7$ \\
\hline & Dig & $155.6 \pm 4.0$ & $198.8 \pm 2.0$ & $192.8 \pm 4.4$ & $159.1 \pm 4.2$ & $176.6 \pm 5.3$ \\
\hline & Dig + St & $149.2 \pm 7.6$ & $180.1 \pm 6.3$ & $200.2 \pm 6.0$ & $159.9 \pm 3.3$ & $172.4 \pm 5.7$ \\
\hline & Csl & $153.7 \pm 7.0$ & $184.0 \pm 1.5$ & $188.5 \pm 1.6$ & $148.2 \pm 1.3$ & $168.6 \pm 4.9$ \\
\hline & NPK & $154.5 \pm 3.8$ & $182.8 \pm 4.2$ & $189.7 \pm 7.4$ & $156.0 \pm 3.9$ & $170.8 \pm 4.6$ \\
\hline \multirow[t]{5}{*}{$\mathrm{Mg}$} & Control & $149.4 \pm 5.6$ & $137.1 \pm 3.3$ & $211.8 \pm 12.1$ & $175.0 \pm 3.1$ & $168.3 \pm 8.0$ \\
\hline & Dig & $141.6 \pm 3.4$ & $141.0 \pm 4.1$ & $195.3 \pm 5.2$ & $177.6 \pm 9.3$ & $163.9 \pm 6.6$ \\
\hline & $\mathrm{Dig}+\mathrm{St}$ & $143.0 \pm 7.0$ & $140.7 \pm 2.1$ & $198.2 \pm 9.4$ & $176.9 \pm 2.1$ & $164.7 \pm 6.8$ \\
\hline & Csl & $137.1 \pm 3.9$ & $132.6 \pm 1.1$ & $198.0 \pm 9.1$ & $167.2 \pm 2.5$ & $158.7 \pm 7.2$ \\
\hline & NPK & $132.9 \pm 3.0$ & $136.5 \pm 1.3$ & $202.3 \pm 5.3$ & $175.4 \pm 3.8$ & $161.8 \pm 7.6$ \\
\hline \multirow[t]{5}{*}{$\mathrm{Ca}$} & Control & $4781 \pm 61$ & $4633 \pm 106$ & $5474 \pm 342$ & $5118 \pm 294$ & $5002 \pm 134$ \\
\hline & Dig & $4686 \pm 126$ & $4902 \pm 76$ & $5396 \pm 431$ & $5218 \pm 185$ & $5051 \pm 131$ \\
\hline & $\mathrm{Dig}+\mathrm{St}$ & $4677 \pm 161$ & $5117 \pm 98$ & $5089 \pm 179$ & $5044 \pm 59$ & $4982 \pm 75$ \\
\hline & Csl & $4555 \pm 56$ & $4688 \pm 108$ & $5046 \pm 133$ & $5417 \pm 450$ & $4926 \pm 144$ \\
\hline & NPK & $4823 \pm 329$ & $4756 \pm 93$ & $5136 \pm 192$ & $5256 \pm 264$ & $4993 \pm 119$ \\
\hline
\end{tabular}

Different letters $(\mathrm{a}, \mathrm{b}, \mathrm{c})$ indicate statistically significant differences between treatments at $p<0.05$ (honest significant difference (HSD) test).

\subsection{Soil Mineral Nitrogen}

In each year, the effect of fertilizer treatments on the content of $\mathrm{NH}_{4}-\mathrm{N}$ and $\mathrm{NO}_{3}-\mathrm{N}$ was analyzed in two terms, spring and autumn. The main factor affecting the content of both forms of mineral $\mathrm{N}$ was the year and season. However, this effect was significantly modified by fertilizer application, regardless of the soil depth. In spring, the $\mathrm{NO}_{3}-\mathrm{N}$ content in topsoil was in the range of 15.3 to $37.0 \mathrm{~kg} \mathrm{ha}^{-1}$, and 
in subsoil it was $15.0-20.8 \mathrm{~kg} \mathrm{ha}^{-1}$, depending on the year. In autumn, the ranges were 15.7 to 22.7 and 15.1 to $20.8 \mathrm{~kg} \mathrm{ha}^{-1}$, respectively. With respect to $\mathrm{NH}_{4}-\mathrm{N}$, soil samples collected in autumn from the $0.0-0.3 \mathrm{~m}$ soil depth contained more of this $\mathrm{N}$ form $\left(1.6-7.0 \mathrm{~kg} \mathrm{ha}^{-1}\right)$ than in spring $\left(1.5-3.7 \mathrm{~kg} \mathrm{ha}^{-1}\right)$.

The fertilization did not exert any significant impact on the mean content of $\mathrm{NH}_{4}-\mathrm{N}$. There was also no significant interaction of factors. The content of $\mathrm{NO}_{3}-\mathrm{N}$ depended, however, on the interaction between the year and fertilizer treatment. In spring 2013, the highest concentration of $\mathrm{NO}_{3}-\mathrm{N}$ in the topsoil was obtained in the control treatment, yet its lowest content was recorded in the NPK treatment. In the following years (2014-2016), the fertilization treatments increased the concentration of $\mathrm{NO}_{3}-\mathrm{N}$ in comparison to control (Table 6). In 2014, the highest concentration of $\mathrm{NO}_{3}-\mathrm{N}$ in topsoil was recorded for the Dig treatment. The obtained value was significantly higher than for the control, Csl, or NPK treatments. In 2015, the highest content of $\mathrm{NO}_{3}-\mathrm{N}$ was also obtained for the Dig treatment. In 2016 the highest concentration of $\mathrm{NO}_{3}-\mathrm{N}$ was recorded for Dig + St. Nevertheless, it did not differ from the values achieved for the other treatments. With regard to its content in the subsoil, the highest concentration in 2013 was obtained in the Dig treatment, which was also the case for 2014 and 2015, and in 2016 the highest concentration was obtained with Dig + St (Table 6).

In the autumn, a significant interaction between factors was found only in the topsoil. In 2013, significant differences were registered between treatments, Dig, Dig + St, Csl, and NPK. In 2014, application of digestate significantly increased the $\mathrm{N}$ content compared to the other treatments. In 2015, digestate application also increased the $\mathrm{NO}_{3}-\mathrm{N}$ content the most, but there was no difference between Dig and Csl. In contrast, in 2016, the highest content of $\mathrm{NO}_{3}-\mathrm{N}$ was found in Dig + St treatment (Table 6).

The total content of $\mathrm{N}_{\min }$ in the spring amounted to $66.3 \mathrm{~kg} \mathrm{ha}^{-1}$ and was by $62.9 \%$ higher than in the autumn. A significant interaction between factors was found for $\mathrm{N}_{\min }$ in the spring and autumn $(p<0.001$ and $p<0.05)$. Between 2013-2015 the highest values were obtained in the Dig treatment, and in 2016, the $\mathrm{N}_{\min }$ reached the highest values in the Dig + St treatment (Figure 1).

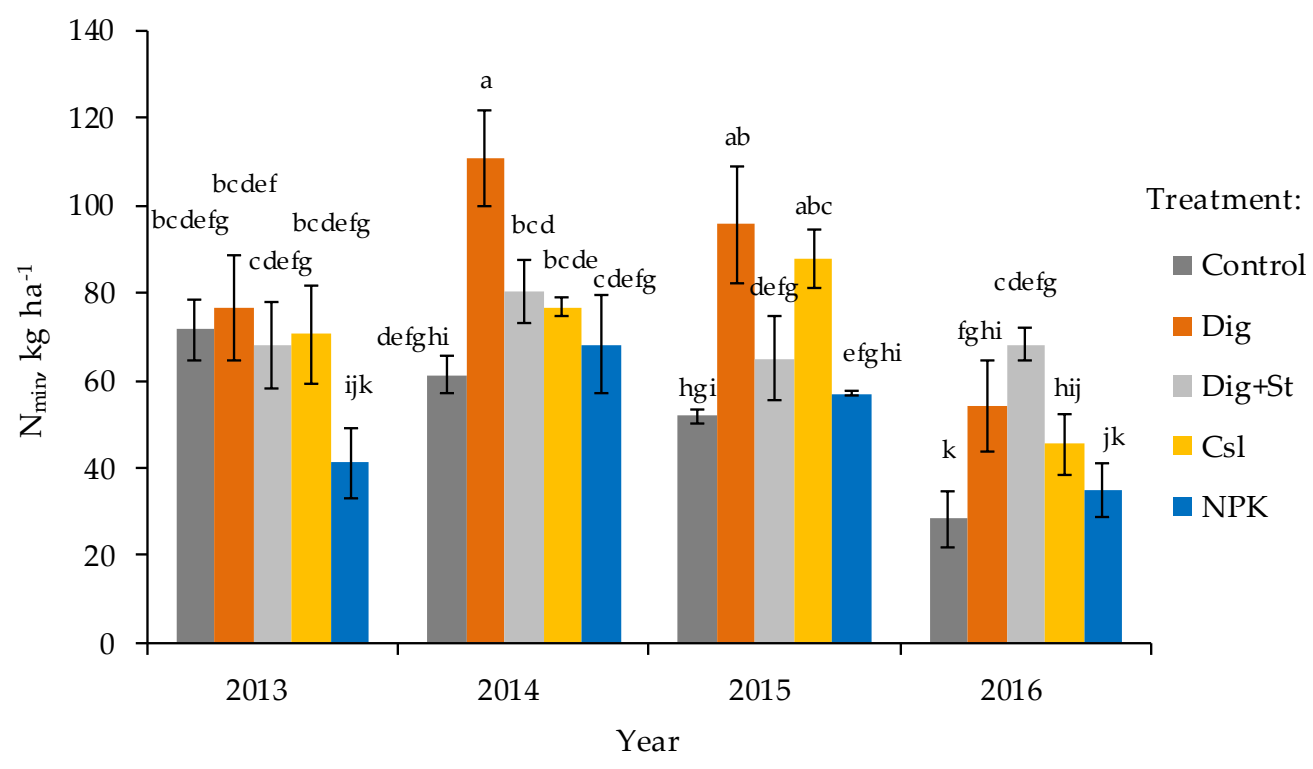

Figure 1. Mineral nitrogen content in $0.0-0.60 \mathrm{~m}$ soil depth (total $\mathrm{N}_{\min }$ ) in spring (before applying mineral $\mathrm{N}$ fertilizers) depending on the interaction between year and fertilizer treatment. Different letters indicate statistically significant differences between treatments (HSD test). Hatched bars represent $2 \times$ SEM ranges. 
Table 6. Mineral nitrogen forms $\left(\mathrm{NH}_{4}-\mathrm{N}\right.$ and $\left.\mathrm{NO}_{3}-\mathrm{N}\right)$ in soil samples $\left(\mathrm{mg} \mathrm{kg}^{-1}\right)$ as a result of interaction between year and fertilizer treatment in spring and autumn.

\begin{tabular}{|c|c|c|c|c|c|c|}
\hline \multirow{2}{*}{ Mineral N } & \multirow{2}{*}{ Season } & \multirow{2}{*}{ Treatment } & \multicolumn{4}{|c|}{ Year } \\
\hline & & & 2013 & 2014 & 2015 & 2016 \\
\hline \multicolumn{7}{|c|}{ Soil depth: $0.0-0.3 \mathrm{~m}$} \\
\hline \multirow[t]{10}{*}{$\mathrm{NH}_{4}-\mathrm{N}$} & Spring & Control & $0.46 \pm 0.02$ & $0.78 \pm 0.09$ & $0.93 \pm 0.09$ & $0.72 \pm 0.12$ \\
\hline & & Dig & $0.31 \pm 0.03$ & $1.09 \pm 0.27$ & $0.99 \pm 0.13$ & $0.88 \pm 0.03$ \\
\hline & & $\mathrm{Dig}+\mathrm{St}$ & $0.37 \pm 0.01$ & $0.83 \pm 0.04$ & $1.05 \pm 0.09$ & $0.94 \pm 0.11$ \\
\hline & & Csl & $0.39 \pm 0.04$ & $0.81 \pm 0.08$ & $0.88 \pm 0.03$ & $0.97 \pm 0.04$ \\
\hline & & NPK & $0.33 \pm 0.01$ & $0.83 \pm 0.09$ & $0.74 \pm 0.05$ & $0.79 \pm 0.14$ \\
\hline & Autumn & Control & $1.70 \pm 0.06$ & $0.92 \pm 0.09$ & $1.13 \pm 0.21$ & $0.56 \pm 0.07$ \\
\hline & & Dig & $1.38 \pm 0.15$ & $0.77 \pm 0.09$ & $1.40 \pm 0.17$ & $0.29 \pm 0.12$ \\
\hline & & Dig + St & $1.86 \pm 0.08$ & $1.36 \pm 0.09$ & $1.10 \pm 0.08$ & $0.36 \pm 0.03$ \\
\hline & & Csl & $1.90 \pm 0.19$ & $1.66 \pm 0.82$ & $1.03 \pm 0.03$ & $0.45 \pm 0.11$ \\
\hline & & NPK & $1.79 \pm 0.16$ & $0.91 \pm 0.21$ & $1.25 \pm 0.15$ & $0.34 \pm 0.13$ \\
\hline \multirow[t]{10}{*}{$\mathrm{NO}_{3}-\mathrm{N}$} & Spring & Control & $6.93 \pm 0.34^{\mathrm{d}, \mathrm{e}, \mathrm{f}, \mathrm{g}}$ & $6.94 \pm 0.12^{c, d, e, f}$ & $5.57 \pm 0.12^{\mathrm{e}, \mathrm{f}, \mathrm{g}}$ & $2.88 \pm 0.12^{j}$ \\
\hline & & Dig & $5.39 \pm 0.07^{\mathrm{e}, \mathrm{f}, \mathrm{g}, \mathrm{h}}$ & $12.60 \pm 1.3^{\mathrm{a}}$ & $10.4 \pm 0.60^{\mathrm{a}, \mathrm{b}}$ & $3.74 \pm 0.06^{\mathrm{h}, \mathrm{i}, \mathrm{j}}$ \\
\hline & & $\mathrm{Dig}+\mathrm{St}$ & $4.63 \pm 0.08 \mathrm{~g}, \mathrm{~h}, \mathrm{i}$ & $10.3 \pm 0.53^{a, b}$ & $7.96 \pm 0.72^{b, c, d, e}$ & $3.96 \pm 0.27^{h, i, j}$ \\
\hline & & Csl & $4.80 \pm 0.02^{\mathrm{f}, \mathrm{g}, \mathrm{h}, \mathrm{i}}$ & $8.77 \pm 0.44^{b, c, d}$ & $9.83 \pm 0.13^{a, b, c}$ & $3.43 \pm 0.28^{j}$ \\
\hline & & NPK & $3.55 \pm 0.29 \mathrm{~h}, \mathrm{i}, \mathrm{j}$ & $8.07 \pm 0.91^{\mathrm{b}, \mathrm{c}, \mathrm{d}, \mathrm{e}}$ & $5.68 \pm 0.12^{e, f, g}$ & $2.82 \pm 0.14^{j}$ \\
\hline & Autumn & Control & $3.94 \pm 0.23^{a, b, c, d}$ & $2.87 \pm 0.09^{d}$ & $5.30 \pm 0.11^{a, b, c}$ & $3.26 \pm 0.12^{c, d}$ \\
\hline & & Dig & $4.29 \pm 0.71^{\mathrm{a}, \mathrm{b}, \mathrm{c}, \mathrm{d}}$ & $6.59 \pm 0.49^{\mathrm{a}}$ & $4.69 \pm 0.34^{\mathrm{a}, \mathrm{b}, \mathrm{c}, \mathrm{d}}$ & $5.13 \pm 0.11^{\mathrm{a}, \mathrm{b}, \mathrm{c}}$ \\
\hline & & $\mathrm{Dig}+\mathrm{St}$ & $4.34 \pm 0.78^{\mathrm{a}, \mathrm{b}, \mathrm{c}, \mathrm{d}}$ & $4.74 \pm 1.18^{\mathrm{a}, \mathrm{b}, \mathrm{c}, \mathrm{d}}$ & $5.81 \pm 0.68^{\mathrm{a}, \mathrm{b}}$ & $3.96 \pm 0.12^{a, b, c, d}$ \\
\hline & & Csl & $3.05 \pm 0.19^{d}$ & $5.81 \pm 0.77^{\mathrm{a}, \mathrm{b}}$ & $5.53 \pm 0.42^{a, b}$ & $4.29 \pm 0.14^{\mathrm{a}, \mathrm{b}, \mathrm{c}, \mathrm{d}}$ \\
\hline & & NPK & $3.76 \pm 0.14^{b, c, d}$ & $5.89 \pm 0.24^{a, b}$ & $6.69 \pm 0.95^{\mathrm{a}}$ & $3.88 \pm 0.33^{a, b, c, d}$ \\
\hline \multicolumn{7}{|c|}{ Soil depth: $0.3-0.6 \mathrm{~m}$} \\
\hline \multirow[t]{10}{*}{$\mathrm{NH}_{4}-\mathrm{N}$} & Spring & Control & $0.56 \pm 0.02$ & $0.71 \pm 0.05$ & $0.68 \pm 0.02$ & $0.71 \pm 0.01$ \\
\hline & & Dig & $0.28 \pm 0.03$ & $0.92 \pm 0.14$ & $0.71 \pm 0.07$ & $0.69 \pm 0.07$ \\
\hline & & $\mathrm{Dig}+\mathrm{St}$ & $0.44 \pm 0.02$ & $0.72 \pm 0.05$ & $0.73 \pm 0.09$ & $0.93 \pm 0.10$ \\
\hline & & Csl & $0.27 \pm 0.02$ & $0.71 \pm 0.03$ & $0.69 \pm 0.03$ & $0.79 \pm 0.05$ \\
\hline & & NPK & $0.32 \pm 0.02$ & $0.97 \pm 0.11$ & $0.73 \pm 0.03$ & $0.76 \pm 0.13$ \\
\hline & Autumn & Control & $1.77 \pm 0.06$ & $0.96 \pm 0.16$ & $0.58 \pm 0.13$ & $0.23 \pm 0.04$ \\
\hline & & Dig & $1.67 \pm 0.08$ & $1.01 \pm 0.14$ & $0.68 \pm 0.05$ & $0.48 \pm 0.09$ \\
\hline & & $\mathrm{Dig}+\mathrm{St}$ & $1.71 \pm 0.04$ & $1.32 \pm 0.25$ & $0.66 \pm 0.10$ & $0.31 \pm 0.07$ \\
\hline & & Csl & $2.34 \pm 0.35$ & $1.08 \pm 0.25$ & $1.02 \pm 0.25$ & $0.34 \pm 0.03$ \\
\hline & & NPK & $1.68 \pm 0.07$ & $1.14 \pm 0.23$ & $0.68 \pm 0.17$ & $0.37 \pm 0.07$ \\
\hline \multirow[t]{10}{*}{$\mathrm{NO}_{3}-\mathrm{N}$} & Spring & Control & $9.05 \pm 0.08^{b, c, d, e}$ & $6.20 \pm 0.77^{\mathrm{e}, \mathrm{f}, \mathrm{g}}$ & $5.18 \pm 0.22^{\mathrm{f}, g}$ & $2.46 \pm 0.15^{\mathrm{h}}$ \\
\hline & & Dig & $12.0 \pm 0.75^{\mathrm{a}, \mathrm{b}}$ & $11.78 \pm 1.25^{\mathrm{a}, \mathrm{b}}$ & $10.75 \pm 1.34^{\mathrm{a}, \mathrm{b}, \mathrm{c}}$ & $7.50 \pm 0.69^{c, d, e, f f}$ \\
\hline & & $\mathrm{Dig}+\mathrm{St}$ & $10.6 \pm 0.31^{a, b, c}$ & $7.45 \pm 0.51^{\mathrm{c}, \mathrm{d}, \mathrm{e}, \mathrm{f}}$ & $5.83 \pm 0.46^{\mathrm{e}, \mathrm{f}, \mathrm{g}}$ & $10.19 \pm 0.47^{a, b, c}$ \\
\hline & & Csl & $11.1 \pm 0.24^{\mathrm{a}, \mathrm{b}, \mathrm{c}}$ & $8.02 \pm 0.07^{c, d, e, f}$ & $9.51 \pm 0.91^{\mathrm{a}, \mathrm{b}, \mathrm{c}, \mathrm{d}}$ & $5.74 \pm 0.53^{\mathrm{e}, \mathrm{f}, \mathrm{g}}$ \\
\hline & & NPK & $5.53 \pm 0.07$ e,f,g & $6.44 \pm 0.62^{\mathrm{d}, \mathrm{e}, \mathrm{f}, \mathrm{g}}$ & $6.40 \pm 0.14^{\mathrm{d}, \mathrm{e}, \mathrm{f}, \mathrm{g}}$ & $3.90 \pm 0.18 \mathrm{~g}, \mathrm{~h}$ \\
\hline & Autumn & Control & $3.82 \pm 0.5$ & $3.18 \pm 0.06$ & $1.14 \pm 0.13$ & $0.64 \pm 0.20$ \\
\hline & & Dig & $4.85 \pm 0.07$ & $6.82 \pm 0.8$ & $3.24 \pm 0.10$ & $0.96 \pm 0.18$ \\
\hline & & $\mathrm{Dig}+\mathrm{St}$ & $4.96 \pm 0.16$ & $4.39 \pm 0.32$ & $2.17 \pm 0.08$ & $0.79 \pm 0.23$ \\
\hline & & Csl & $5.48 \pm 1.29$ & $5.64 \pm 0.38$ & $2.44 \pm 0.10$ & $0.64 \pm 0.28$ \\
\hline & & NPK & $5.23 \pm 0.19$ & $5.30 \pm 0.20$ & $2.23 \pm 0.14$ & $0.81 \pm 0.12$ \\
\hline
\end{tabular}

Different letters $(\mathrm{a}, \mathrm{b}, \mathrm{c}, \mathrm{d}, \mathrm{e}, \mathrm{f}, \mathrm{g}, \mathrm{h}, \mathrm{i}, \mathrm{j})$ indicate statistically significant differences between treatments at $p<0.05$ (honest significant difference (HSD) test).

In the autumn, only in 2014 were significant differences between the treatments found. A significant difference was registered between two treatments: control and Dig (Figure 2). 


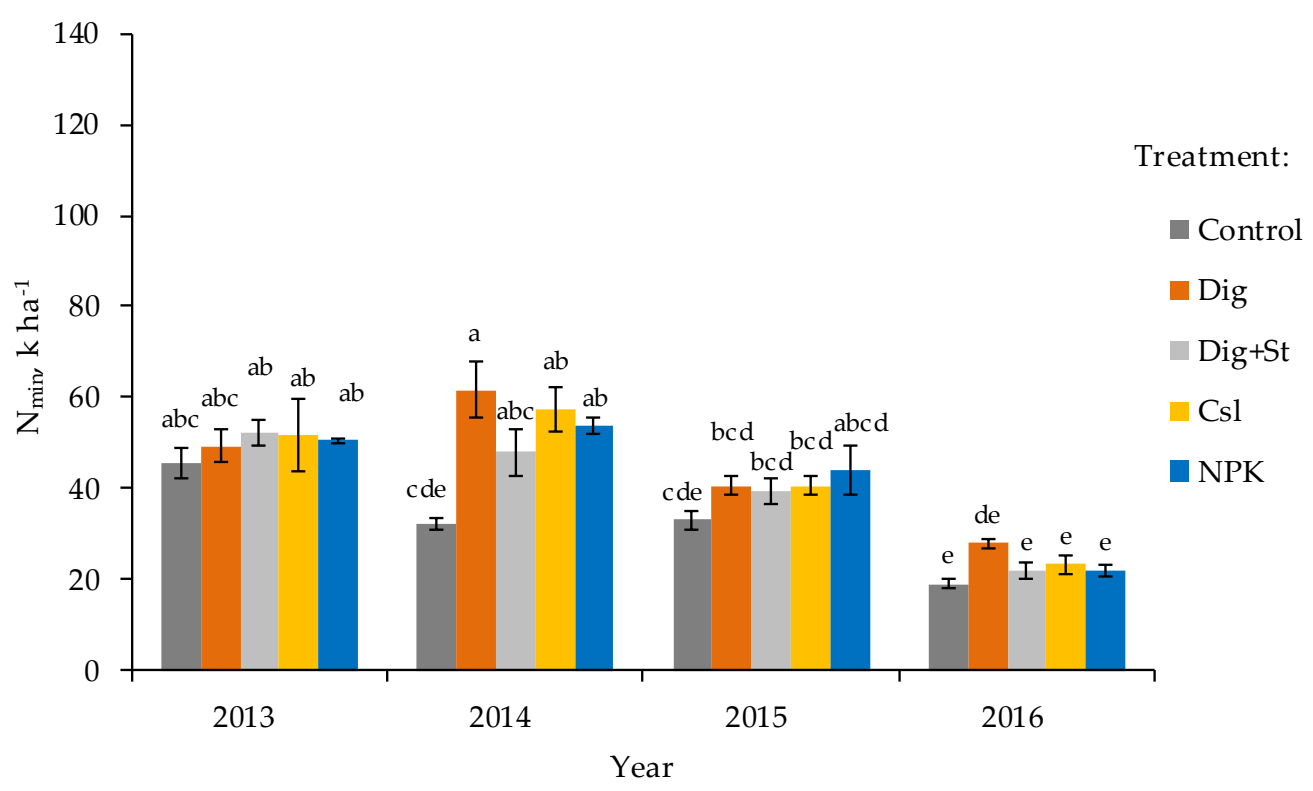

Figure 2. Mineral nitrogen content in $0.0-0.60 \mathrm{~m}$ soil depth (total $\mathrm{N}_{\min }$ ) in autumn (after harvest) depending on the interaction between year and fertilizer treatment. Different letters indicate statistically significant differences between treatments (HSD test). Hatched bars represent $2 \times$ SEM ranges.

\subsection{Principal Component Analysis}

Three PCs were discriminated (distinguished) for each soil depth. The PCs explained $76.8 \%$ and $87.7 \%$ of the total variability in soil characteristics for $0.0-0.3$ and $0.3-0.6 \mathrm{~m}$ soil layers, respectively. The set of variables significantly associated with PCs was specific to soil layer. For the topsoil, significant $\mathrm{PF}_{1}$ loadings were exerted by $\mathrm{SOC} / \mathrm{TN}, \mathrm{pH}, \mathrm{NH}_{4}-\mathrm{N} /$ autumn, and $\mathrm{NH}_{4}-\mathrm{N} /$ spring. Variables representing $\mathrm{NO}_{3}-\mathrm{N} /$ autumn and $\mathrm{NO}_{3}-\mathrm{N} /$ spring had the highest loadings in $\mathrm{PC}_{2}$. The set of $\mathrm{PC}_{3}$ determinants was composed of $\mathrm{TN}, \mathrm{Mg}$, and $\mathrm{P}$ (Table S2).

As shown in Figure 3a, the studied soil parameters can be divided into two groups. The first group includes $\mathrm{SOC} / \mathrm{TN}, \mathrm{pH}, \mathrm{NH}_{4}-\mathrm{N} /$ autumn, and $\mathrm{SOC}$, and the second group consists of $\mathrm{TN}, \mathrm{K}$, $\mathrm{NO}_{3}-\mathrm{N} /$ autumn, and $\mathrm{NO}_{3}-\mathrm{N} /$ spring. There was a negative correlation between variables representing the content of plant-available $\mathrm{Ca}$ and $\mathrm{Mg}$, and variables constituted by SOC and plant-available P. However, as shown on the $\mathrm{PC}_{1}-\mathrm{PC}_{3}$ axes, some data for $\mathrm{SOC}$ positively correlated with $\mathrm{Ca}$ and $\mathrm{Mg}$ (Figure $3 \mathrm{~b}$ ). In respect to subsoil, the set of $\mathrm{PF}_{1}$ determinants was composed of $\mathrm{SOC}, \mathrm{TN}, \mathrm{pH}, \mathrm{P}$, $\mathrm{NH}_{4}-\mathrm{N} /$ autumn, and $\mathrm{NH}_{4}-\mathrm{N} /$ spring. Variables representing $\mathrm{Mg}$ and $\mathrm{Ca}$ had the highest loadings in $\mathrm{PC}_{2}$. As shown on the $\mathrm{PC}_{1}-\mathrm{PC}_{2}$ axes, $\mathrm{SOC}$ and $\mathrm{TN}$ were negatively associated only with the variables representing $\mathrm{Ca}$ and $\mathrm{Mg}$ content (Figure 3c). On the $\mathrm{PC}_{1}-\mathrm{PC}_{3}$ axes, the values of SOC, TN, and $\mathrm{NH}_{4}$-N/autumn were also closely interconnected (Figure 3d). 


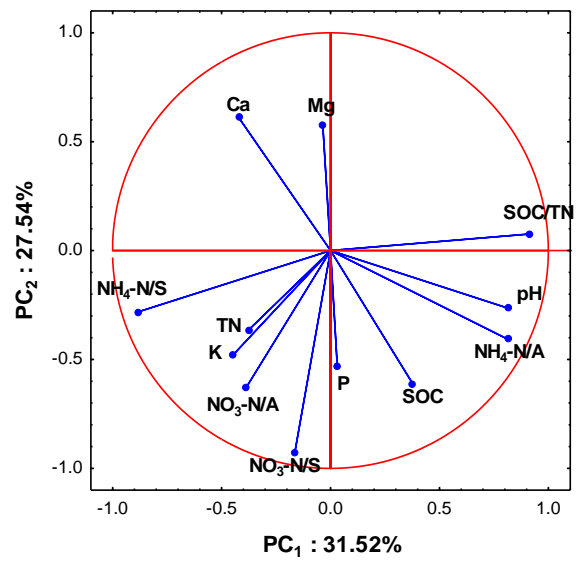

(a)

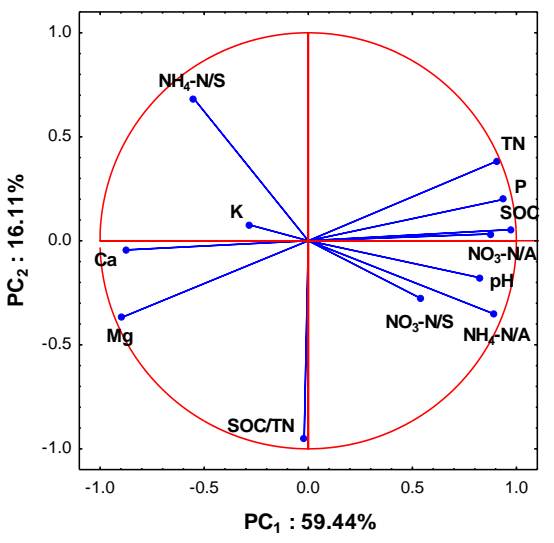

(c)

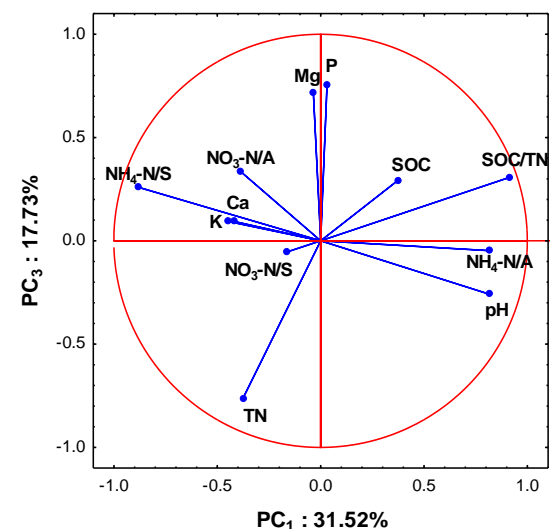

(b)

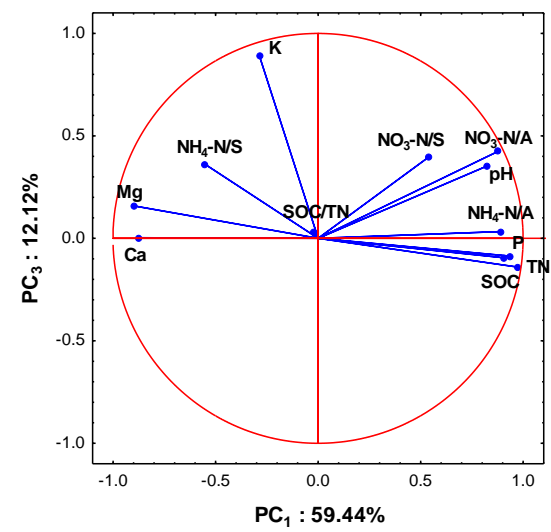

(d)

Figure 3. Principal component analysis (PCA) of studied soil parameters: projection of active variables on PCA factor plane for two soil layers: $(\mathbf{a}, \mathbf{b}) 0.0-0.3 \mathrm{~m}$ and $(\mathbf{c}, \mathbf{d}) 0.3-0.6 \mathrm{~m}$. A, autumn; S, spring.

\section{Discussion}

Compared to the control and the NPK treatment, fertilization with digestate and cattle slurry did not increase the concentration of SOC and TN in soil in a significant way. Only an upward trend was visible, especially in subsoil. In contrast, Odlare et al. [25] showed a considerable difference in the content of SOC and TN between control and treatments with organic and mineral fertilizers. However, that study took eight years, which was twice as long as the one presented here. Moreover, the experiment was carried out on soil with lower $\mathrm{pH}$ and lower SOC concentration. According to Odlare et al. [25], SOC in the last year of the study was the highest in the compost treated soil, whereas biogas residues showed similar results to the NPK treatment. It was nonetheless related to a higher rate of organic matter $(\mathrm{OM})$ used in a form of compost rather than digestate. The observed lack of variation between NPK treatment and treatments with organic fertilizers (Dig, Csl) was probably a result of the short duration of the experiment.

In general, long-term application of mineral fertilizers (NPK) without any OM input can accelerate humus mineralization and lead to reduction of SOC [41]. In our studies, no significant difference was observed in the response reaction of Dig and Csl treatments to SOC and TN. Earlier results also indicated no variation between undigested and $\left(\mathrm{CO}^{-}\right)$digested slurry treatments in the formation of SOC, especially in field conditions [30,32]. According to Möller [6] this can be explained by the fact that $C$ losses during the anaerobic digestion process are compensated by lower $C$ degradation after fertilizer application in the field, whereas Johansen et al. [8] suggest that digestate would, in the long-term, impair SOC. Therefore, in our study, straw was an additional source of C in the soil (Dig + St 
treatment). In a two-year study, Tivari et al. [34] indicated that simultaneous application of wheat straw nodes and biogas slurry (in a 1:4 ratio) improved soil physicochemical and biological properties. Other authors pointed out that the straw fertilization increased SOC content in soil [35]. However, our study did not confirm a positive impact of Dig + St treatment on SOC content when compared with straw-free treatment (Dig), also including NPK treatment. This could have been caused by (i) a lower supply of post-harvest residues, such as stubble in the Dig + St treatment compared with the Dig treatment, or (ii) higher susceptibility of straw to mineralization and $\mathrm{C}$ losses in the form of $\mathrm{CO}_{2}$ [29]. Other authors also reported that straw reincorporated into soil exerted little or even negative influence on SOC content $[42,43]$. No significant relationship was found between SOC and NT in the topsoil. The results of Bai et al. [44] indicate that the correlation between SOC and NT depends on many factors, including soil texture, temperature, and moisture. In addition, the content of SOC and TN in the soil is controlled by different groups of microorganisms [45-47]. In contrast to topsoil, there was a positive correlation between variables representing SOC and TN in subsoil.

In each year of the study, an upward trend of plant-available P content was observed in topsoil and subsoil after application of digestate and/or cattle slurry. As result, a significant increase of its mean concentration was recorded in Csl and Dig treatments compared with control and NPK treatment (Table 5). The last relationship is particularly interesting because the dose of P in the NPK treatment was two times higher than in the Csl and Dig treatments. The main factors affecting plant-available $\mathrm{P}$ content are $\mathrm{P}$ dose, soil $\mathrm{pH}$, soil temperature, and moisture [26]. Application of manure and organic fertilizers may influence $P$ availability in the soil either directly, through an application of inorganic and organic $\mathrm{P}$ compounds, or indirectly, by prompting the activity of soil microorganisms as a consequence of the supply of organic C [24]. Moreover, natural and organic fertilizers, including digestates, can be a source of protons $\left(\mathrm{H}^{+}\right)$and lead to soil acidification [48]. In our study, the soil was characterized by high amounts of $\mathrm{Ca}$, and $\mathrm{pH}$ did not depend on fertilization. Therefore, it is very likely that organic acid anions from organic matter of cattle slurry and digestate might compete for sorption sites with Pi (ligand exchange), thereby reducing the $\mathrm{P}$ adsorption capacity by Ca compounds. In our study, moreover, the content of $\mathrm{P}$ in soil was higher in Csl treatment than in Dig. According to Bahmann et al. [23], the ratio between readily soluble $\mathrm{P}$ fractions and total $\mathrm{P}$ content in digestates was more than $70 \%$, which was more than in case of feedstock, where the content of readily soluble P fractions was lower. As a result, the application of digestates increased the content of plant-available $\mathrm{P}$ in the soil to the same extent as highly soluble TSP. Bahmann et al. [24] also reported that P content was higher in the feedstock than in the digestate amended soil. This is due to the difference in enzyme activity (dehydrogenase and alkaline phosphatase), in particular on alkaline soils [49]. In our studies the soil pH was just on the border of neutral and alkaline. According to our research, the addition of straw did not increase the plant-available $\mathrm{P}$ content in soil, which probably resulted from the biological immobilization.

In contrast to $\mathrm{P}$, straw application had a significant impact on the content of plant-available $\mathrm{K}$. Straw contains relatively more $\mathrm{K}$ than cereal grains, and it is an important source of $\mathrm{K}$ in crop rotation [50]. As the earlier studies show, digestate may also be a valuable source of $K$ in soil [3,21]. In our study, the increased plant-available $\mathrm{K}$ in soil after digestate and straw application comparing control, NPK, and Csl treatments probably resulted from a stimulation of cereal straw decomposition [6] and/or ion exchange of $\mathrm{NH}_{4}+/ \mathrm{K}^{+}$in spaces between sheets of clay minerals [51].

A number of scientific reports confirm the highest fertilizer values of $\mathrm{N}$ from digestate compared to traditional manure and organic fertilizers such as cattle slurry, solid manure, sewage sludge, or/and green manure [52-54]. The applied fertilizers considerably affected the content of $\mathrm{NO}_{3}-\mathrm{N}$. However, the effect of fertilizers was significantly modified by the year of study. In general, the applied fertilizers, especially digestate and cattle slurry, considerably affected the content of $\mathrm{NO}_{3}-\mathrm{N}$. In line with the previous observations, this form of $\mathrm{N}$ was dominant in soil (80-90\%) and well explained the differences in the content of total $N_{\min }$ [55]. Since the rate of $N$ in the NPK treatment was higher than in the Dig and Csl treatments, the differences came from a gradual accumulation and mineralization of organic $\mathrm{N}$ or remineralization of immobilized manure $\mathrm{NH}_{4}-\mathrm{N}$ [7]. A higher content of $\mathrm{NO}_{3}-\mathrm{N}$ was observed 
in soil treated with Dig than with Csl. Earlier studies also showed that fertilizing with anaerobically digested materials increased the soil content of $\mathrm{NO}_{3}-\mathrm{N}$ by about $30-40 \%$, compared to treatment where raw cattle slurry was applied [8]. In the author's own study, the difference between Dig and Csl treatments in terms of $\mathrm{NO}_{3}-\mathrm{N}$ content was $19.1-22.2 \%$, depending on the soil depth. This arises from the fact that lower levels of $\mathrm{CO}_{2}$ are produced from less biodegradable digested materials, and $\mathrm{NH}_{4}-\mathrm{N}$ is rapidly nitrified in soil, making it an available N source for crops [29]. Moreover, volatile fatty acids, present in pig or cattle slurry, slow down $\mathrm{NH}_{3}$ oxidation [56]. Increased concentration of $\mathrm{NH}_{4}-\mathrm{N}$ in digestate could also have enhanced the activity of microorganisms and the content of $\mathrm{N}_{\min }$ in soil as a result of the so-called priming effect. On the other hand, a high rate of mineral N in the NPK treatment led to an opposite effect, and the priming effect was inhibited [57].

In our study, incorporation of straw into soil with digestate decreased $\mathrm{N}_{\min }$ content. In general, when organic amendments with a $\mathrm{C} / \mathrm{N}$ ratio above 20 are added to soil, net $\mathrm{N}$ assimilation by microbiota dominates [45]. Over time, when easily mineralized organic C (straw) is depleted, $\mathrm{N}$ immobilization disappears. These findings have been indirectly confirmed by our studies, as each year the largest discrepancies in $\mathrm{N}_{\min }$ content between Dig and Dig + St treatments were observed in spring, not in autumn. However, in the fourth year of the experiment, the incorporation of straw into the soil did not initiate the biological effect of nitrogen immobilization. It is worth mentioning that in the autumn of 2016 the lowest content of $\mathrm{NO}_{3}-\mathrm{N}$ was recorded, caused by a drought that year (Figure S1).

\section{Conclusions}

Our findings indicate that the short-term use of digestate, cattle slurry, and straw significantly modified the content of plant-available $\mathrm{P}$ and $\mathrm{K}$ as well as mineral $\mathrm{N}$ in soil. The cattle slurry fertilization had a positive effect on the average content of plant-available $\mathrm{P}$ and the incorporation of straw before the digestate application increased the content of plant-available $\mathrm{K}$ in topsoil. In regard to mineral $\mathrm{N}$, the differences between the fertilization treatments significantly depended on year, soil sampling season, and soil depth. In topsoil, after the second year of the experiment, a positive effect of digestate on soil $\mathrm{NO}_{3}-\mathrm{N}$ content was revealed, especially in spring. In contrast to the plant-available nutrients and mineral $\mathrm{N}$, the four-year study showed that application of digestate, cattle slurry, and straw did not affect the SOC and TN content in the soil compared to mineral NPK fertilization.

Supplementary Materials: The following are available online at http://www.mdpi.com/2073-4395/10/3/379/s1, Figure S1: Mean monthly air temperature and sum of precipitation during 2012-2016 growing seasons of winter wheat and spring barley, Figure S2: Soil reaction $(\mathrm{pH})$ depending on the year and fertilization treatment, Table S1: Total content of phosphorus, sulfur, copper, manganese and zinc in soil samples as a result of application of digestate (Dig), digestate + straw (Dig + St), cattle slurry (Csl) and mineral fertilizers (NPK), Table S2: Correlation matrix loadings and variance of the significant principal components (PCs) for soil quality properties depending on soil depth.

Author Contributions: Conceptualization, E.K.; Methodology, P.B. and E.K; Validation, P.B.; Formal analysis, P.B.; Investigation, L.H.; Resources, L.H. and E.K.; Data Curation, L.H. and P.B.; Writing-original draft preparation, L.H. and P.B.; Writing-review and editing, L.H. and P.B; Visualization, L.H. and P.B.; supervision, E.K.; Project administration, E.K. All authors have read and agreed to the published version of the manuscript.

Funding: This research received no external funding.

Acknowledgments: The writing of the paper was supported by the Ministry of Agriculture of the Czech Republic by project MZe-RO0418, and by the Ministry of Science and Higher Education of Poland by project 005/RID/2018/19.

Conflicts of Interest: The authors declare no conflict of interest.

\section{References}

1. Al Seadi, T.; Drosg, B.; Fuchs, W.; Rutz, D.; Janssen, R. Biogas digestate quality and utilization. In The Biogas Handbook. Science, Production and Applications; Wellinger, A., Murphy, J., Baxter, D., Eds.; Woodhead Publishing Limited: Oxford/Cambridge, UK; Philadelphia, PA, USA; New Delhi, India, 2013; pp. $267-301$. [CrossRef] 
2. Alburquerquea, J.A.; de la Fuente, C.; Campoy, M.; Carrasco, L.; Nájera, I.; Baixauli, C.; Caravaca, F.; Roldán, A.; Cegarra, J.; Bernal, M.P. Agricultural use of digestate for horticultural crop production and improvement of soil properties. Eur. J. Agron. 2012, 43, 119-128. [CrossRef]

3. Möller, K.; Müller, T. Effects of anaerobic digestion on digestate nutrient availability and crop growth: A review. Eng. Life Sci. 2012, 12, 242-257. [CrossRef]

4. Logan, M.; Visvanathan, C. Management strategies for anaerobic digestate of organic fraction of municipal solid waste: Current status and future prospects. Waste Manag. Res. 2019, 37 (Suppl. S1), 27-39. [CrossRef] [PubMed]

5. Arthurson, V. Closing the global energy and nutrient cycles through application of biogas residue to agricultural land-Potential benefits and drawbacks. Energies 2009, 2, 226-242. [CrossRef]

6. Möller, K. Effects of anaerobic digestion on soil carbon and nitrogen turnover, $\mathrm{N}$ emissions, and soil biological activity. A review. Agron. Sustain. Dev. 2015, 35, 1021-1041. [CrossRef]

7. Gutser, R.; Ebertseder, T.; Weber, A.; Schraml, M.; Schmidhalter, U. Short-term and residual availability of nitrogen after long-term application of organic fertilizers on arable land. J. Plant Nutr. Soil Sci. 2005, 168, 439-446. [CrossRef]

8. Johansen, A.; Carter, M.S.; Jensen, E.S.; Hauggard-Nielsen, H.; Ambus, P. Effects of digestate from anaerobically digested cattle slurry and plant materials on soil microbial community and emission of $\mathrm{CO}_{2}$ and $\mathrm{N}_{2} \mathrm{O}$. Appl. Ecol. 2013, 63, 36-44. [CrossRef]

9. Sogn, T.A.; Dragicevic, I.; Linjordet, R.; Krogstad, T.; Eijsink, V.G.H.; Eich-Greatorex, S. Recycling of biogas digestates in plant production: NPK fertilizer value and risk of leaching. Recycl. Org. Waste Agric. 2018, 7, 49-58. [CrossRef]

10. Tambone, F.; Adani, F. Nitrogen mineralization from digestate in comparison to sewage sludge, compost and urea in a laboratory incubated soil experiment. J. Plant Nutr. Soil Sci. 2017, 180, 355-365. [CrossRef]

11. Fontaine, S.; Mariotti, A.; Abbadie, L. The priming effect of organic matter: A question of microbial competition? Soil Biol. Biochem. 2003, 35, 837-843. [CrossRef]

12. Abubaker, J.; Risberg, K.; Pell, M. Biogas residues as fertilisers-Effects on wheat growth and soil microbial activities. Appl. Energ. 2012, 99, 126-134. [CrossRef]

13. Mason-Jones, K.; Schmücker, N.; Kuzyakov, Y. Contrasting effects of organic and mineral nitrogen challenge the N-mining hypothesis for soil organic matter priming. Soil Biol. Biochem. 2018, 124, 38-46. [CrossRef]

14. Edelmann, W.; Baier, U.; Engeli, H. Environmental aspects of the anaerobic digestion of the organic fraction of municipal solid wastes and of agricultural wastes. Water Sci. Technol. 2005, 52, 203-208. [CrossRef] [PubMed]

15. Möller, K.; Stinner, W. Effects of different manuring systems with and without biogas digestion on soil mineral nitrogen content and on gaseous nitrogen losses (ammonia, nitrous oxides). Eur. J. Agron. 2009, 30, 1-16. [CrossRef]

16. Goberna, M.; Podmirseg, S.M.; Waldhuber, S.; Knapp, B.A.; García, C.; Insam, H. Pathogenic bacteria and mineral $\mathrm{N}$ in soil following the land spreading of biogas digestates and fresh manure. Appl. Soil Ecol. 2011, 49, 18-25. [CrossRef]

17. Nicholson, F.A.; Bhogal, A.; Rollett, A.; Taylor, M.; Williams, J.R. Precision application techniques reduce ammonia emissions following food-based digestate applications to grassland. Nutr. Cycl. Agroecosyst. 2018, 110, 151-159. [CrossRef]

18. Van der Eerben, L.J.M.; de Visser, P.H.B.; van Dijk, C.J. Risk of damage to crops in the direct neighborhood of ammonia sources. Environ. Pollut. 1998, 102, 49-53. [CrossRef]

19. Nkoa, R. Agricultural benefits and environmental risks of soil fertilization with anaerobic digestates: A review. Agron. Sustain. Dev. 2014, 34, 473-492. [CrossRef]

20. Insam, H.; Gomez-Brand, M.; Ascher, J. Manure-based biogas fermentation residues-Friend or foe of soil fertility? Soil Biol. Biochem. 2015, 84, 1-14. [CrossRef]

21. Zhang, C.; Yun, S.; Li, X.; Wang, Z.; Xu, H.; Du, T. Low-cost composited accelerants for anaerobic digestion of dairy manure: Focusing on methane yield, digestate utilization and energy evaluation. Bioresour. Technol. 2018, 263, 17-524. [CrossRef]

22. Zirkler, D.; Peters, A.; Kaupenjohann, M. Elemental composition of biogas residues: Variability and alteration during anaerobic digestion. Biomass Bioenergy 2014, 67, 89-98. [CrossRef] 
23. Bachmann, S.; Uptmoor, R.; Eichler-Löbermann, B. Phosphorus distribution and availability in untreated and mechanically separated biogas digestates. Sci. Agric. 2016, 73, 9-17. [CrossRef]

24. Bachmann, S.; Gropp, M.; Eichler-Löberman, B. Phosphorus availability and soil microbial activity in a 3 year field experiment amended with digested dairy slurry. Biomass Bioenergy 2014, 70, 429-439. [CrossRef]

25. Odlare, M.; Arthurson, V.; Pell, M.; Svensson, K.; Nehrenheim, E.; Abubaker, J. Land application of organic waste-Effects on the soil ecosystem. Appl. Energy 2011, 88, 2210-2218. [CrossRef]

26. Penn, C.J.; Camberato, J.J. A Critical review on soil chemical processes that control how soil $\mathrm{pH}$ acts phosphorus availability to plants. Agriculture 2019, 9, 120. [CrossRef]

27. Bolster, C.H.; Sistani, K.R. Sorption of phosphorus from swine dairy and poultry manures. Commun. Soil Sci. Plan Anal. 2009, 40, 1106-1123. [CrossRef]

28. Oburger, E.; Jones, D.L.; Wenzel, W.W. Phosphorus saturation and pH differentially regulate the efficiency of organic acid anion-mediated P solubilization mechanisms in soil. Plant Soil 2011, 341, 363-382. [CrossRef]

29. Alburquerque, J.A.; de la Fuente, C.; Bernal, M.P. Chemical properties of anaerobic digestates affecting C and $\mathrm{N}$ dynamics in amended soils. Agric. Ecosyst. Environ. 2012, 160, 15-22. [CrossRef]

30. Möller, K. Effects of biogas digestion on soil organic matter and nitrogen inputs, flows and budgets in organic cropping systems. Nutr. Cycl. Agroecosyst. 2009, 84, 179-202. [CrossRef]

31. Thomsen, I.K.; Olesen, J.E.; Møller, H.B.; Sørensen, P.; Christensen, B.T. Carbon dynamics and retention in soil after anaerobic digestion of dairy cattle feed and faeces. Soil Biol. Biochem. 2013, 58, 82-87. [CrossRef]

32. De la Fuente, C.; Alburquerque, J.A.; Clemente, R.; Bernal, M.P. Soil C and N mineralisation and agricultural value of the products of an anaerobic digestion system. Biol. Fertil. Soils 2013, 49, 313-322. [CrossRef]

33. Tambone, F.; Scaglia, B.; D’Imporzano, G.; Schievano, A.; Orzi, V.; Salati, S.; Adani, F. Assessing amendment and fertilizing properties of digestates from anaerobic digestion through a comparative study with digested sludge and compost. Chemosphere 2010, 81, 577-583. [CrossRef] [PubMed]

34. Tiwari, V.; Tiwari, K.; Upadhyay, R. Effect of crop residues and biogas slurry incorporation in wheat on yield and soil fertility. J. Indian Soc. Soil Sci. 2000, 48, 515-520.

35. Liu, C.; Lu, M.; Cui, J.; Li, B.; Fang, C. Effects of straw carbon input on carbon dynamics in agricultural soils: A meta-analysis. Global Chang. Biol. 2014, 20, 1366-1381. [CrossRef] [PubMed]

36. Bai, Y.; Wang, L.; Lu, Y.; Zhou, L.; Ni, L.; Cheng, M. Effects of long-term full straw return on yield and potassium response in wheat-maize rotation. J. Integr. Agric. 2015, 14, 2467-2476. [CrossRef]

37. Wang, W.; Sardans, S.; Wang, C.; Pan, T.; Zeng, C.; Lai, D.Y.I.; Bartrons, B.; Peñuelas, J. Straw application strategy to optimize nutrient release in a southeastern china rice cropland. Agronomy 2017, 7, 84. [CrossRef]

38. World Reference Base for Soil Resources 2014. Word Soil Resources Reports, 106; Food and Agriculture Organization of the United Nations: Rome, Italy, 2015; Available online: www.fao.org/3/a-i3794e.pdf (accessed on 11 December 2019).

39. Mehlich, A. Mehlich 3 soil test extractant: A modification of Mehlich 2 extractant. Commun. Soil Sci. Plan Anal. 1984, 15, 1409-1416. [CrossRef]

40. StatSoft Inc. Electronic Statistics Textbook; StatSoft Inc.: Tulsa, OK, USA, 2013; Available online: http: //www.statsoft.com/textbook/ (accessed on 13 October 2019).

41. Menšík, L.; Hlisnikovský, L.; Pospíšilová, L.; Kunzová, E. The effect of application of organic manures and mineral fertilizers on the state of soil organic matter and nutrients in the long-term field experiment. J. Soils Sediments 2018, 18, 2813-2822. [CrossRef]

42. Stumpe, B.; Werner, S.; Jung, R.; Heinze, S.; Jüschke, S.; Strippel, C.; Marschner, B. Organic carbon dynamics and enzyme activities in agricultural soils amended with biogas slurry, liquid manure and sewage sludge. Agric. Sci. 2012, 3, 104-113. [CrossRef]

43. Garcia-Orenes, F.; Cerdá, A.; Mataix-Solera, J.; Guerrero, C.; Bodí, M.B. Effects of agricultural management on surface soil properties and soil-water losses in eastern Spain. Soils Tillage Res. 2009, 106, 117-123. [CrossRef]

44. Bai, J.; Ouyang, H.; Deng, W.; Zhu, Y.; Zhang, X.; Wang, Q. Spatial distribution characteristics of organic matter and total nitrogen of marsh soils in river marginal wetlands. Geoderma 2005, 124, 181-192. [CrossRef]

45. Abubaker, J.; Cederlund, H.; Arthurson, V.; Pell, M. Bacterial community structure and microbial activity in different soils amended with biogas residues and cattle slurry. Appl. Soil Ecol. 2015, 72, 171-180. [CrossRef]

46. Cameron, K.C.; Di, H.J.; Moir, J.L. Nitrogen losses from the soil/plant system: A review. Ann. Appl. Biol. 2013, 162, 145-173. [CrossRef] 
47. Johansson, M.; Stenberg, B.; Torstensson, L. Microbiological and chemical changes in two arable soils after long-term sludge amendments. Biol. Fertil. Soils 1999, 30, 160-167. [CrossRef]

48. Makádi, M.; Tomócsik, A.; Orosz, V. Digestate: A New Nutrient Source-Review. In Biogas; Kumar, S., Ed.; InTech Europe: Rijeka, Croatia, 2012; pp. 295-310.

49. Galvez, A.; Sinicco, T.; Cayuela, M.L.; Mingorance, M.D.; Fornasier, F.; Mondini, C. Short term effects of bioenergy by-products on soil $\mathrm{C}$ and $\mathrm{N}$ dynamics, nutrient availability and biochemical properties. Agric. Ecosyst. Environ. 2012, 160, 3-14. [CrossRef]

50. Zhao, S.; He, P.; Qiu, S.; Jia, L.; Liu, M.; Jin, J.; Johnston, A.M. Long-term effects of potassium fertilization and straw return on soil potassium levels and crop yields in north-central China. Field Crops Res. 2014, 169, 116-122. [CrossRef]

51. Chappell, M.A.; Evangelou, V.P. Influence of added $\mathrm{K}^{+}$on ammonium selectivity/mobility by soils with vermiculitic behavior. Soil Sci. 2000, 165, 858-868. [CrossRef]

52. Cavalli, D.; Cabassi, G.; Borrelli, L.; Geromel, G.; Bechini, L.; Degano, L.; Gallina, P.M. Nitrogen fertilizer replacement value of undigested liquid cattle manure and digestates. Eur. J. Agron. 2016, 73, 34-41. [CrossRef]

53. De Notaris, C.; Sørensen, P.; Møller, H.B.; Wahid, R.; Eriksen, J. Nitrogen fertilizer replacement value of digestates from three green manures. Nutr. Cycl. Agroecosyst. 2018, 112, 355-368. [CrossRef]

54. Barłóg, P.; Hlisnikovský, L.; Kunzová, E. Yield, content, and nutrient uptake by winter wheat and spring barley in response to applications of digestate, cattle slurry, and NPK mineral fertilizers. Arch. Agron. Soil Sci. 2019, 1-6. [CrossRef]

55. Barłóg, P.; Łukowiak, R.; Grzebisz, W. Predicting the content of soil mineral nitrogen based on the content of calcium chloride-extractable nutrients. J. Plant Nutr. Soil Sci. 2017, 180, 624-635. [CrossRef]

56. Risberg, K.; Cederlund, H.; Pell, M.; Arthurson, V.; Schnürer, A. Comparative characterization of digestate versus pig slurry and cow manure-Chemical composition and effects on soil microbial activity. Waste Manag. 2017, 61, 529-538. [CrossRef] [PubMed]

57. Kuzyakov, Y. Review: Factors effecting rhizosphere priming effects. J. Plant Nutr. Soil Sci. 2002, 165, 382-396. [CrossRef]

(C) 2020 by the authors. Licensee MDPI, Basel, Switzerland. This article is an open access article distributed under the terms and conditions of the Creative Commons Attribution (CC BY) license (http://creativecommons.org/licenses/by/4.0/). 